\title{
Aktivitas Antibakteri Metabolit Sekunder dari Ekstrak Metanol Biji Alpukat (Persea americana Mill)
}

\author{
Rini Retnosari, Sutrisno, dan Karim Handoyo \\ Jurusan Kimia, FMIPA \\ Universitas Negeri Malang \\ rini.retnosari.fmipa@um.ac.id
}

\begin{abstract}
Abstrak
Metabolit sekunder yang memiliki aktivitas antibakteri telah diisolasi dari ekstrak metanol biji alpukat (Parsea americana Mill). Proses isolasi diawali dengan ekstraksi menggunakan metanol, dilanjutkan dengan fraksinasi dan pemisahan menggunakan berbagai teknik kromatografi seperti kromatografi cair vakum (KCV) dan kromatografi kolom gravitasi (KKG). Dari proses isolasi tersebut diperoleh komponen K-1 yang berwujud padat dan berwarna putih. Komponen K-1 mempunyai titik lebur $67-70^{\circ} \mathrm{C}$, larut dalam kloroform, etil asetat, dan etanol. Komponen K-1 mempunyai $\lambda$ maks pada $219,0 \mathrm{~nm}$ mengindikasikan adanya transisi $\pi \pi^{*}$ dan $344,0 \mathrm{~nm}$ mengindikasikan adanya transisi $\mathrm{n} \pi^{*}$. Berdasarkan hasil interpretasi spektrum IR, komponen ini mengandung gugus $-\mathrm{OH}$, gugus $-\mathrm{C}=\mathrm{O}$ ester, ikatan $-\mathrm{CH}$, dan ikatan $\mathrm{C}=\mathrm{C}$. Komponen $\mathrm{K}-1$ diduga golongan saponin. Uji aktivitas antibakteri terhadap pertumbuhan bakteri Escherichia coli dan Staphylococcus aureus mengindikasikan ekstrak metanol biji alpukat dan komponen K-1 aktif sebagai antibakteri, sehingga kedepannya memiliki prospek bagi pengembangan obat tradisional.
\end{abstract}

Kata-kata kunci: biji alpukat (Parsea americana Mill), ekstrak metanol, aktivitas antibakteri

\begin{abstract}
An antibacterial activity of secondary metabolite has been isolated from methanol extract of avocado seed (Parsea americana Mill). The isolation process has started with extracting using methanol, then fractioning and purifying by chromatography technique such as vacuum liquid chromatography and gravitation column chromatography. The white solid of $K-1$ component has been isolated from this process. The melting point of $K-1$ component was $67-70^{\circ} \mathrm{C}$ and dissolved in chloroform, ethyl acetate, and ethanol. $\mathrm{K}-1$ component has $\lambda$ maks at 219,0 $\mathrm{nm}\left(\pi \rightarrow \pi^{*}\right.$ transition) and 344,0 $\mathrm{nm}\left(n \rightarrow \pi^{*}\right.$ transition). Based on IR spectrum interpretation, this component contained $-\mathrm{OH}$ group, $-\mathrm{C}=\mathrm{O}$ group of ester, $-\mathrm{CH}$ bond, and $\mathrm{C}=\mathrm{C}$ bond. $\mathrm{K}-1$ component was predicted as saponin group. The antibacterial activity assay against Escherichia coli and Staphylococcus aureus indicated that methanol extract of avocado seed and K-1 component showed antibacterial activity toward both bacteria, so that this component has future chances for traditional medicine development.
\end{abstract}

Keywords: avocado seed (Parsea americana Mill), methanol extract, antibacterial activity

\section{PENDAHULUAN}

Tumbuhan alpukat merupakan salah satu tanaman yang melimpah di Indonesia. Kelimpahan buah alpukat ditunjukkan oleh data produksi buahbuahan di Indonesia, yang mana produksi buah alpukat mengalami peningkatan dari tahun 20132014 dengan persentase pertumbuhan sebesar 6,01\% (Badan Pusat Statistik dan Direktorat Jenderal Hortikultura, 2014). Masyarakat umumnya hanya menggunakan daging buah alpukat, seperti dijadikan jus buah, masker perawatan wajah, dan perawatan rambut. Namun biji alpukat kurang termanfaatkan dan dibuang menjadi limbah.

Berbagai riset tentang khasiat dan potensi biji alpukat telah dilakukan. Dua senyawa turunan asam absisat yaitu asam $\beta$-D-glukosida-(1'S,6'R)-8'hidroksi absisat dan asam $\beta$-D-glukosida(1'R,3'R,5'R,8'S)-epi-dihidropaseat berhasil diisolasi dari biji alpukat (Ramos, dkk., 2004). Ekstrak metanol biji alpukat mengandung 6 senyawa turunan 1,2,4-trihidroksi dekana dan 2 senyawa turunan 1,2,4-trihidroksi nonadekana yang berpotensi sebagai antiinsektida terhadap Trypanosoma cruzi (Abe, dkk., 2005).

Biji alpukat juga mengandung asam klorogenat, 3-hidroksi-tirosol-1' - $\beta$-D-O-glukosida, tirosol-1'- $\beta$ -D-O-glukosida, dua senyawa turunan dimer proantosianidin, trimer proantosianidin-A2-(+)katekin dan trimer proantosianidin-A2-(-)-epikatekin 
(Ramos-Jerz, dkk., 2013). Enam senyawa turunan lemak juga berhasil diisolasi dari ekstrak aseton biji alpukat yaitu (2S,4S)-1-asetoksi-2,4-dihidroksi-nheptadeka-16-en, (2R,16E)-1-asetoksi-2-hidroksi-4okso-nona deka-16,18-dien, (2R,5E,16E)-1-asetoksi2-hidroksi-4-okso-nonadeka-5, 16-dien, (2R,5E,12Z,15Z)-1-asetoksi-2-hidroksi-4-okso heneikosa-5,12,15-trien, (5E)-1-asetoksi-2-hidroksi4-okso-nonadeka-5-en, (2R,12Z,15Z)-1-asetoksi-2hidroksi-4-okso-heneikosa-12,15-dien. Keenam senyawa tersebut memiliki aktivitas antijamur terhadap sel vegetatif dan endospora Clostridium sporogenes sehingga berpotensi sebagai zat aditif dan antibiotik pada industri makanan dan farmasi untuk menghambat pertumbuhan bakteri gram positif (Rodríguez-Sánchez, dkk., 2013).

Potensi lain dari biji alpukat yaitu ekstrak airnya dapat menurunkan tekanan darah, kolesterol, LDL, dan triasilgliserol pada tikus yang menderita hipertensi (Imafidon, dkk., 2010; Anaka, dkk., 2009). Ekstrak air biji alpukat juga dapat menurunkan kadar glukosa darah sehingga dapat digunakan untuk mengobati penyakit diabetes (Edem, dkk., 2009). Ekstrak biji alpukat juga memiliki aktivitas antioksidan karena mengandung senyawa polifenolik yaitu trimer prosianidin A sehingga dapat digunakan sebagai zat aditif makanan (Kosińska, dkk., 2012).

Selain memiliki aktivitas antiinsektida, antijamur, antihipertensi, antidiabetes, dan antioksidan, biji alpukat juga berpotensi sebagai antibakteri. Penelitian yang dilakukan oleh Chia \& Dykes (2010) menunjukkan bahwa ekstrak etanol biji alpukat memiliki aktivitas antibakteri $\quad(\mathrm{MIC}=104.2-416.7$ $\mathrm{g} / \mathrm{mL}$ ) terhadap bakteri gram positif dan gram negatif kecuali Escherichia coli, sedangkan ekstrak air biji alpukat hanya menunjukkan aktivitas antibakteri terhadap Listeria monocytogenes (MIC = 93.8-375.0 g/mL) dan Staphylococcus epidermidis $(\mathrm{MIC}=354.2 \mathrm{~g} / \mathrm{mL})$. Namun penelitian yang dilakukan oleh Sutrisno, dkk. (2013) menunjukkan bahwa ekstrak nonpolar (heksana dan kloroform) biji alpukat memiliki aktivitas antibakteri terhadap Escherichia coli.

Berdasarkan penelusuran literatur diatas, biji alpukat kaya akan senyawa turunan asam absisat, senyawa turunan lemak, dan senyawa fenolik. Penelusuran aktivitas antibakteri hanya terbatas pada ekstrak etanol, air, heksana, dan kloroform saja. Oleh karena itu studi dan riset tentang aktivitas antibakteri terhadap ekstrak metanol biji alpukat dan metabolit sekunder yang terkandung dalam ekstrak tersebut perlu dilakukan.

\section{METODE}

Alat yang digunakan antara lain adalah seperangkat peralatan maserasi, seperangkat peralatan KCV, seperangkat peralatan KKG, seperangkat alat Kromatografi Lapis Tipis (KLT), seperangkat alat rotary vacuum evaporator (rotavapor) Buchi, Fischer Scientific Melting Point Apparatus, seperangkat spektrofotometer UV-Vis Shimadzu 1601, seperangkat spektrofotometer FTIR Shimadzu IR-prestige 21, autoklaf, laminar flow, shaker, inkubator, jarum ose, cawan petri, microtube, jangka sorong, erlenmeyer dan peralatan gelas lainnya. Bahan yang digunakan adalah biji alpukat, metanol, n-heksana, etil asetat, kloroform, aseton, etanol, silika gel 60 GF254, silika gel $60(0,063-$ $0,200 \mathrm{~mm})$, silika gel $60(0,2-0,5 \mathrm{~mm})$, pelat KLT dengan lapisan silika gel 60 F254 pada pelat aluminium, kertas cakram, dimetil sulfoksida (DMSO), ampicilin, nutrient broth, nutrient agar, dan bakteri biakan murni Staphylococcus aureus dan Escherichia coli (keduanya diperoleh dari Laboratorium Mikrobiologi Jurusan Biologi FMIPA, Universitas Negeri Malang.

\section{Preparasi Sampel}

Biji alpukat dicuci hingga bersih, dipotong kecilkecil, dikeringkan dan ditimbang sampai diperoleh berat konstan. Kemudian rajangan biji alpukat digiling hingga menjadi serbuk, dan selanjutnya bahan ini yang digunakan sebagai sampel penelitian ini.

\section{Isolasi Komponen K-1 dari Ekstrak Metanol Biji Alpukat}

Serbuk biji alpukat $(1 \mathrm{~kg})$ yang telah kering diekstraksi dengan cara maserasi menggunakan pelarut metanol (1 Liter) secara berulang-ulang sampai diperoleh maserat tidak berwarna. Maserat dievaporasi dengan rotavapor sehingga diperoleh ekstrak metanol hasil maserasi. Sebanyak $10 \mathrm{~g}$ ekstrak metanol difraksinasi dengan cara KCV menggunakan eluen $n$-heksana, $n$-heksana:etil asetat (9:1 sampai dengan 1:9), etil asetat, dan metanol menghasilkan 15 fraksi. Fraksi 4 dan 5 memiliki noda yang identik sehingga dapat digabung. Oleh karena fraksi 4 dan $5(0,396 \mathrm{~g})$ memiliki noda paling sederhana dan massa paling banyak maka dipisahkan lebih lanjut menggunakan KKG dengan eluen n-heksana:etil asetat $=8: 2$ menghasilkan 62 fraksi. Fraksi hasil KKG ini selanjutnya dianalisis KLT. Fraksi-fraksi dengan $\mathrm{R}_{f}$ yang sama (pada hasil KLT) selanjutnya dikumpulkan menjadi satu fraksi. Proses pemurnian dengan KKG dilanjutkan hingga diperoleh fraksi yang memiliki pola noda tunggal. Fraksi-fraksi yang 
diduga memiliki noda tunggal selanjutnya dianalisis KLT dengan tiga sistem pelarut yaitu (a) $n$ heksana:etil asetat $=8: 2$, (b) $n$-heksana:etil asetat $=$ 7:3, dan (c) kloroform $100 \%$. Fraksi yang diduga memiliki noda tunggal selanjutnya dikarakterisasi sifat fisika dan kimia, serta interpretasi spektrum UV dan IR.

\section{Karakterisasi Komponen Hasil Isolasi}

Karakterisasi zat hasil isolasi meliputi meliputi sifat fisik (wujud dan warna, penentuan titik lebur, dan uji kelarutan), sifat kimia (uji golongan senyawa bahan alam), serta interpretasi spektrum UV dan IR.

\section{Uji Aktivitas Antibakteri}

Uji aktivitas antibakteri dilakukan menggunakan metode difusi cakram. Pada metode ini kontrol positif yang digunakan adalah ampisilin dan kontrol negatif adalah dimetilsulfoksida (DMSO). Sampel uji yang digunakan terdiri dari $0,0025 \mathrm{~g}$ sampel dilarutkan dalam $0,5 \mathrm{~mL}$ DMSO sehingga diperoleh konsentrasi sebesar 5000 ppm (Valgas, et al., 2007). Uji aktivitas antibakteri ekstrak metanol biji alpukat dan komponen hasil isolasi dilakukan dengan terlebih dahulu membuat media cair, media padat, dan mensterilisasikan semua peralatan yang akan digunakan. Tahap selanjutnya yaitu membuat biakan murni bakteri $E$. coli dan $S$. aureus yang distandarisasi dengan larutan Mc. Farland 0,5 sehingga diperoleh biakan bakteri uji (E. coli dan $S$. aureus) dengan kepadatan mikroba sebanyak $1,5 \times 105 \mathrm{sel} / \mathrm{mL}$ larutan biakan. Uji daya hambat antibakteri merujuk pada. Bakteri biakan murni $(S$. aureus dan E. coli) dalam NC diinokulasikan ke dalam media NA dengan menggunakan cotton bud steril. Kertas cakram yang telah dipersiapkan direndam dengan larutan uji selama 15 menit. Kertas cakram yang telah direndam diletakan pada media NA yang telah diinokulasi bakteri, kemudian diinkubasi pada suhu $37^{\circ} \mathrm{C}$ selama $1 \times 24$ jam. Setelah 1x24 jam diameter zona hambat pertumbuhan bakteri uji diukur menggunakan jangka sorong.

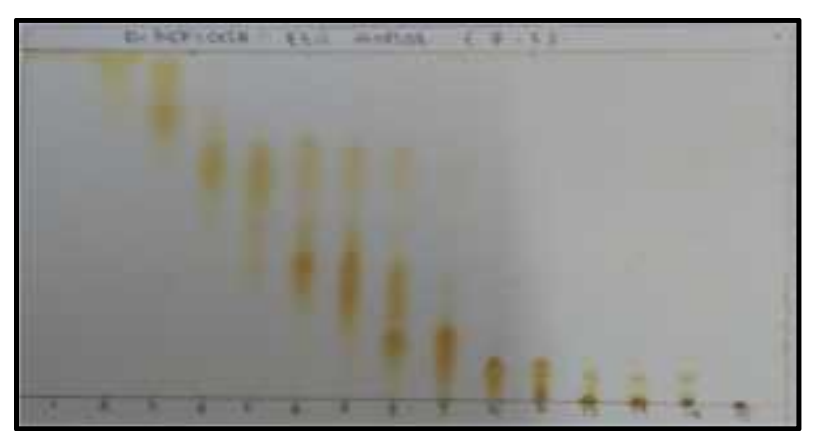

Gambar 1. Kromatogram Fraksi-fraksi Hasil KVC

\section{HASIL DAN PEMBAHASAN}

Sebanyak 1000 gram serbuk kering biji alpukat dimaserasi dengan metanol dihasilkan ekstrak kental berwarna coklat kehitaman sebanyak 130,43 gram. Ekstrak metanol selanjutnya difraksinasi menggunakan teknik KCV menghasilkan 15 fraksi utama 1-15. Kromatogram hasil KLT fraksi-fraksi hasil KVC menggunakan eluen ( $n$-heksana:etil asetat =7:3) ditunjukkan pada Gambar 1 .

Fraksi 4 dan 5 (0,396 g) dimurnikan lebih lanjut dengan teknik KKG menghasilkan komponen K-1 sebanyak $29 \mathrm{mg}$. Analisis KLT komponen K-1 dengan tiga sistem pelarut menunjukkan masingmasing satu noda; (1) $n$-heksana:etil asetat $(8: 2)$, (2) $n$-heksana:etil asetat (7:3), dan (3) kloroform $100 \%$ seperti terlihat pada Gambar 2. Data fisikokimia tersebut menunjukkan bahwa komponen K-1 relatif murni.

Komponen K-1 berwujud padat berwarna putih dengan titik lebur $67-70^{\circ} \mathrm{C}$. Berdasarkan hasil uji kelarutan menunjukkan bahwa komponen K-1 sedikit larut pada $n$-heksana, larut sempurna pada kloroform, etil asetat, dan etanol serta tidak larut pada metanol dan air. Oleh karena itu, komponen K1 memiliki kepolaran yang relatif rendah. Berdasarkan hasil uji golongan senyawa bahan alam mengindikasikan bahwa komponen K-1 merupakan golongan saponin.

Spektrum UV komponen K-1 hasil isolasi ditunjukkan pada Gambar 3. Spektrum UV ini menunjukkan serapan maksimum pada $\lambda_{\text {maks }} 219,0$ $\mathrm{nm}$ dengan absorptivitas (a) sebesar $8,80 \mathrm{~cm}^{2} \cdot \mathrm{mg}^{-1}$ dan $\lambda_{\text {maks }} 344,0 \mathrm{~nm}$ dengan absorptivitas (a) sebesar $0,10 \mathrm{~cm}^{2} \cdot \mathrm{mg}^{-1}$. Pada $\lambda_{\text {maks }} 219 \mathrm{~nm}$ diduga terjadi transisi $\pi \rightarrow \pi^{*}$ yang mengindikasikan adanya suatu ikatan rangkap karbon-karbon. Pada $\lambda_{\text {maks }} 340 \mathrm{~nm}$ diduga terjadi transisi $\mathrm{n} \rightarrow \pi^{*}$ dari pasangan elektron bebas gugus karbonil.

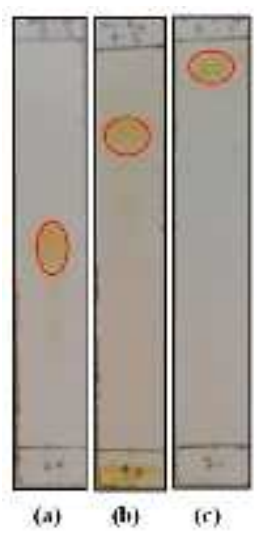

Gambar 2. Analisis KLT Komponen K-1 dengan Tiga Sistem Pelarut 


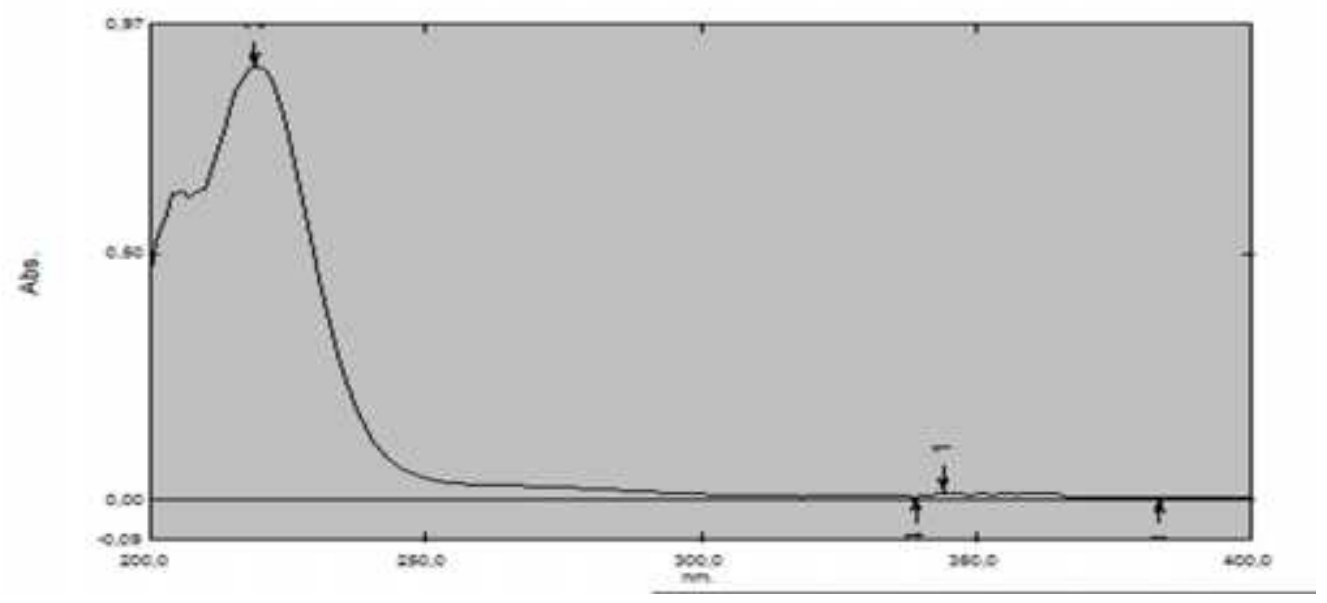

Gambar 3. Spektrum UV Komponen K-1 Hasil Isolasi

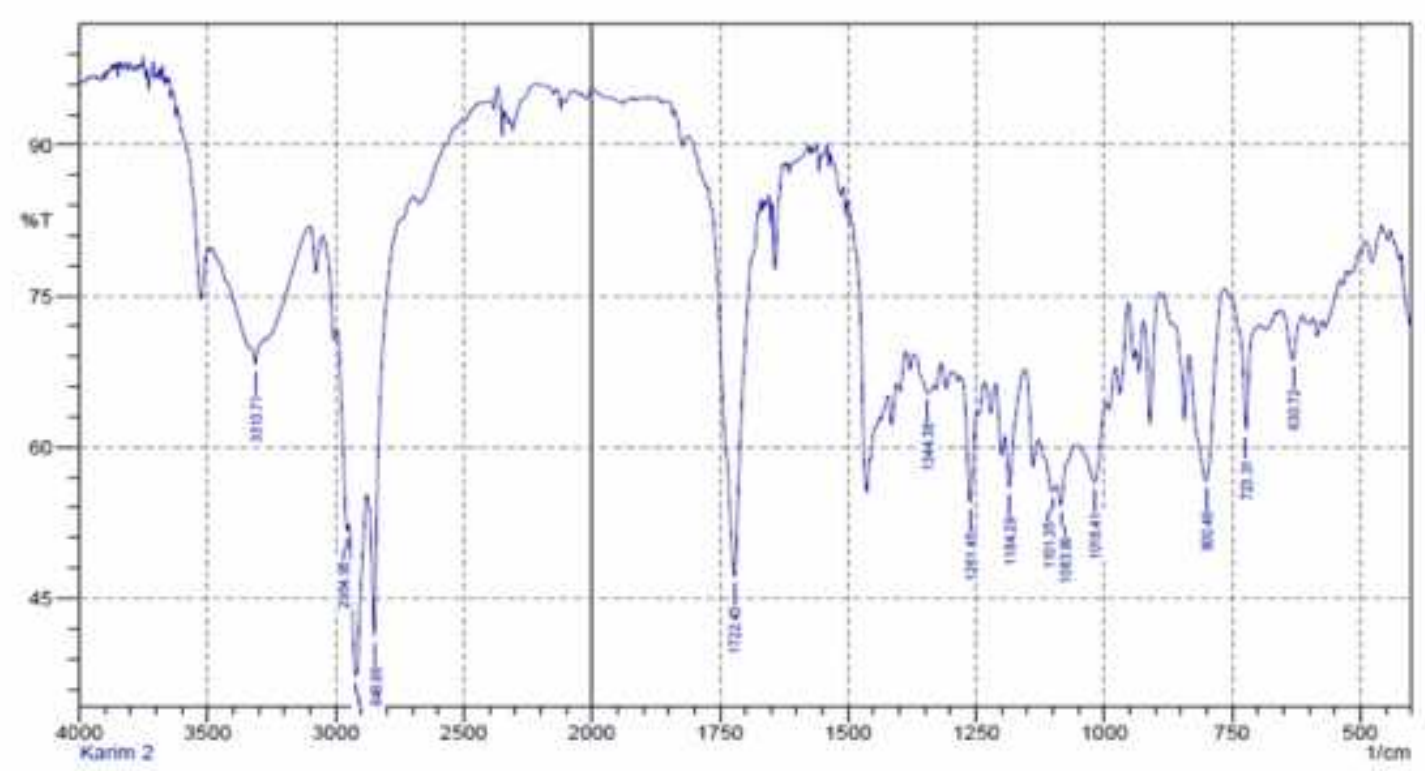

Gambar 4. Spektrum IR Komponen K-1 Hasil Isolasi

Tabel 1. Diameter Zona Hambat Sampel terhadap E. coli dan $S$.

\begin{tabular}{|c|c|c|c|c|}
\hline \multirow[b]{2}{*}{ Nama Sampel } & \multicolumn{4}{|c|}{ Zona Hambat terhadap E. coli $(\mathrm{mm})$} \\
\hline & $\begin{array}{c}\text { Bagian } \\
1\end{array}$ & $\begin{array}{c}\text { Bagian } \\
2\end{array}$ & $\begin{array}{l}\text { Bagian } \\
3\end{array}$ & $\begin{array}{r}\text { Rata- } \\
\text { rata }\end{array}$ \\
\hline Ekstrak metanol & 6,95 & 8,15 & 8,50 & 7,87 \\
\hline Fraksi 4 & 11,25 & 9,55 & 12,25 & 11,02 \\
\hline Komponen K-1 & 8,30 & 7,60 & 6,70 & 7,53 \\
\hline $\begin{array}{l}\text { Kontrol (+) } \\
\text { Ampisilin }\end{array}$ & 16,35 & 18,65 & 17,85 & 17,62 \\
\hline Kontrol (-) DMSO & 6 & 6 & 6 & 6 \\
\hline \multirow[b]{2}{*}{ Nama Sampel } & \multicolumn{4}{|c|}{ Zona Hambat terhadap S. aureus $(\mathrm{mm})$} \\
\hline & $\begin{array}{c}\text { Bagian } \\
1\end{array}$ & $\begin{array}{c}\text { Bagian } \\
2\end{array}$ & $\begin{array}{c}\text { Bagian } \\
3\end{array}$ & $\begin{array}{l}\text { Rata- } \\
\text { rata }\end{array}$ \\
\hline Ekstrak metanol & 8,25 & 7,45 & 7,95 & 7,88 \\
\hline Fraksi 4 & 9,40 & 9,40 & 9,40 & 9,40 \\
\hline Komponen K-1 & 8,75 & 6,10 & 6,80 & 7,22 \\
\hline $\begin{array}{l}\text { Kontrol (+) } \\
\text { Ampisilin }\end{array}$ & 17,15 & 17,15 & 17,15 & 17,15 \\
\hline Kontrol (-) DMSO & 6 & 6 & 6 & 6 \\
\hline
\end{tabular}

Spektrum IR komponen K-1 ditunjukkan pada Gambar 4. Spektrum ini menunjukkan adanya gugus $-\mathrm{OH}$ pada serapan $3313,17 \mathrm{~cm}^{-1}$, gugus $\mathrm{C}=\mathrm{O}$ ester pada serapan $1722,43 \mathrm{~cm}^{-1}, \mathrm{C}-\mathrm{H}$ alifatik muncul pada serapan $2920,23 \mathrm{~cm}^{-1}$, dan serapan ikatan $C=C$ pada $1650-1590 \mathrm{~cm}^{-1}$. Berdasarkan karakteristik dan analisis spektrum UV dan IR dapat disimpulkan bahwa komponen K-1 merupakan golongan saponin yang memiliki gugus fungsi $-\mathrm{OH},-\mathrm{C}=\mathrm{O}$ dan $\mathrm{C}=\mathrm{C}$.

Uji aktivitas antibakteri ekstrak metanol biji alpukat, fraksi 4, dan komponen K-1 terhadap Escherichia coli dan Staphylococcus aureus menunjukkan hasil yang positif sehingga mengindikasikan adanya aktivitas antibakteri. Hasil uji dapat dilihat pada Tabel 1.

Diameter zona hambat fraksi 4 lebih besar daripada komponen K-1, sehingga diduga masih ada komponen pada fraksi 4 yang memiliki aktivitas antibakteri yang lebih besar dibandingkan komponen $\mathrm{K}-1$. 


\section{KESIMPULAN}

Komponen K-1, hasil isolasi metabolit sekunder dari ekstrak metanol biji alpukat berwujud padat, berwarna putih, dan memiliki titik lebur $67-70^{\circ} \mathrm{C}$. Komponen K-1 larut dalam kloroform, etil asetat, dan etanol, sedikit larut dalam n-heksana, tidak larut dalam metanol dan air. Berdasarkan spektrum UV dan IR, komponen K-1 mengandung ikatan C-H alifatik, gugus $\mathrm{OH}$, gugus karbonil, gugus $\mathrm{C}=\mathrm{O}$ ester,

\section{DAFTAR PUSTAKA}

Abe, F., Nagafuji, S., Okawa, M., Kinjo, J., Akahane, H., Ogura, T., Matinez-Alfaro, M.A., \& Reyes-Chilpa, R. 2005. Trypanocidal Constituents in Plants 5. ${ }^{1)}$ Evaluation of Some Mexican Plants for Their Trypanocidal Activity and Active Constituents in the Seeds of Persea americana. Biol. Pharm. Bull., 28(7): 13141317.

Anaka, O.N., Ozolua, R.I., \& Okpo, S.O. 2009. Effect of the aqueous seed extract of Persea americana Mill (Lauraceae) on the blood pressure of spraguedawley rats. African Journal of Pharmacy and Pharmacology. 3(10), 485-490.

Badan Pusat Statistik dan Direktorat Jenderal Hortikultura. 2014. Produktivitas Buahbuahan di Indonesia. Jakarta: Kementerian Pertanian RI.

Chia, T.W.R., \& Dykes, G.A., 2010. Antimicrobial Activity of Crude Epicarp and Seed Extracts from Mature Avocado Fruit (Persea americana) of Three Cultivars. Pharmaceutical Biology, 48(7): 753-756.

Edem, D., Ekanem, I., \& Ebong, P. 2009. Effect of Aqueous Extracts of Alligator Pear Seed (Persea americana Mill) on Blood Glucose and Histopathology of Pancreas In AlloxanInduced Diabetic Rats. J. Pharm. Sci, 22(3), 272- 276.

Imafidon, K.E. \& Amaechina, F.C. 2010. Effects of Aqueous Seed Extract of Persea americana Mill (Avocado) on Blood Pressure and Lipid Profile in Hypertensive Rats. Advan. Biol. Res., 4(2): 116-121. dan ikatan $\mathrm{C}=\mathrm{C}$. Hasil uji golongan senyawa bahan alam komponen K-1 diduga merupakan golongan saponin. Ekstrak metanol biji alpukat, fraksi 4, dan komponen K-1 menunjukkan adanya aktivitas antibakteri terhadap Escherichia coli dan Staphylococcus aureus. Oleh karena itu, perlu dilakukan penelitian lanjutan untuk mengetahui struktur komponen K-1 dan penyelidikan aktivitas antibakteri komponen pada fraksi yang lebih polar.

Kosińska, A., Karamać, M., Hernández, T., Bartolomé, B., \& Dykes, G.A. 2012. Phenolic compound profiles and antioxidant capacity of Persea americana Mill peels and seeds of two varieties. J. Agric. Food Chem., 60(18): 4613-4619.

Ramos, M.R., Jerz, G., Villaneuva, S., LópezDellamary, F., Waibel, R., \& Winterhalter, P. 2004. Two glucosylated abscisic acid derivates from avocado seeds (Persea americana Mill. Lauraceae $c v$. Hass). Phytochemistry, 65, 955-962.

Ramos, M.R., Villaneuva, S., Jerz, G., Winterhalter, P., \& Deters, A.M. 2013. Persea americana Mill. Seed: Fractionation, Characterization, and Effects on Human Keratinocytes and Fibroblasts. EvidenceBased Complementary and Alternative Medicine, (online), (http://dx.doi.org/10. 1155/2013/391247), diakses 16 Februari 2016.

Rodríguez-Sánchez, D.G., Pacheco, A., GarcíaCruz, M.I., Gutierrez-Uribe, J.A., Benavides, J., \& Hernandez-Brenes, C. 2013. Isolation and Structure Elucidation of Avocado Seed (Persea americana) Lipid Derivatives that Inhibit Clostridium sporogenes Endospore Germination. $J$. Agric. Food. Chem, (online), (http://pubs.acs.org), diakses 16 Februari 2016.

Sutrisno, Marfu'ah, S., \& Oktaviana, L. 2013. Ekstraksi Fraksi Non-Polar dari Biji Alpukat Persea Americana Mill dan Uji Aktivitas sebagai Antibakteri. Prosiding Seminar Nasional Kimia dan Pendidikan HKI Cabang Sumbar, Padang, 7 Desember 2013. 
Valgas, C., Souza, S.M.d., Smânia, E.F., \& Smânia Jr, A. 2007. Screening methods to determine antibacterial activity of natural products. Brazilian Journal of Microbiology, 38(2), 369-380. 